This is an author produced version of a paper published in Small-scale Forestry.

This paper has been peer-reviewed and is proof-corrected, but does not include the journal pagination.

Citation for the published paper:

Solveig Berg Lejon, Lina Holmgren \& Gun Lidestav. (2011) Assessing Small-Scale Forestry by Data Base for Forest Owner Analysis. Small-scale Forestry. Volume: 10, Number: 2, pp 199-210. http://dx.doi.org/10.1007/s11842-011-9157-z.

Access to the published version may require journal subscription. Published with permission from: Springer Netherlands.

Standard set statement from the publisher:

The original publication is available at www.springerlink.com at http://link.springer.com/article/10.1007/s11842-011-9157-z.

Epsilon Open Archive http://epsilon.slu.se 


\title{
Assessing Small-Scale Forestry by Data Base for Forest Owner Analysis
}

Solveig Berg Lejon • Lina Holmgren • Gun Lidestav

Accepted: 25 January 2011 / Published online: 6 February 2011 C)

Steve Harrison, John Herbohn 2011

\begin{abstract}
In Sweden, as in other countries with a growing and increasingly diverse population of forest owners, there is an apparent need for more detailed quantitative data of high quality in order to describe and understand present forest conditions and predict and explain future trends. Therefore, the Swedish University of Agricultural Sciences has developed a Data Base for Forest Owner Analysis (DBFOA) by combining existing forest measurement statistics, gathered on a regular basis by the Swedish Forest Agency since 1992, with records of the individual forest owners. The database consists of selfreported measurement statistics in terms of cuttings, cleaning, scarification and planting from about 30,000 forest management units. It includes information on the owner age, gender, residential proximity to the management unit and the extent of work undertaken by the owner. From 1999 it also indicates whether the forest is certified. This paper demonstrates the use of the database by presenting results from (1) a comparison of management practices on properties that are certified with those that are not, and (2) an examination of how the area of planting and final felling have changed from 1999 to 2006 in total and between male and female forest owners. Results from the first analysis show that the willingness to certify increases with the size of the forest property and also that harvesting activities are more frequent on certified than non-certified properties. The second analysis, show a higher ratio of final felling during 2003-2006 on properties owned by women than properties owned by men.
\end{abstract}

Keywords Consecutive data collection, Management behaviour . Smallscale forest owners, Sweden

S. Berg Lejon . L. Holmgren . G. Lidestav Department of Forest Resource Management, Swedish University of Agricultural Sciences, $90183 \mathrm{Umea}^{\circ}$, Sweden e-mail: Gun.Lidestav@slu.se 


\section{Introduction}

This paper addresses three subject matters put forward by Hyttinen and Kallio (2001) in their report on an attempt to establish guidelines for farm forestry accountancy: (1) small scale-scale forest owners have a key role in implementing various policies such as sustainable forest management and rural development; (2) due to the large number of owners and an increased diversity among them, there is a rising demand for current information on their business activities including structural matters; and (3) there is a lack of harmonized methods to measure, monitor and compare the economic sustainability of a substantial part of the European forestry. However, the context and setting referred to in this paper are confined to Swedish conditions and limited to some basic socioeconomic aspects.

Half of the Swedish forest land, or about $11 \mathrm{M}$ ha, is in the hands of about 350,000 small-scale forest owners. In addition to their traditional role of producing timber for the forest industry, new and increasing expectations and demands from the public and society as a whole have arisen, comprehensively covered by the concept of Sustainable Forest Management, SFM (Appelstrand 2007; Swedish government 2008). Although difficult to define explicitly, SFM as an internationally recognized concept can briefly be explained by the following thematic elements as key components: (1) extent of forest resources; (2) biological diversity; (3) forest health and vitality; (4) productive functions of forest resources; (5) protective functions of forest resources; (6) socio-economic functions; and (7) legal, policy and institutional framework (FAO, 2010). From a Swedish point of view, a series of governmental and market-based actions can be identified since the adaption of the 'Forest Principles' at the United Nations Conference on Environment and Development (UNCED) in Rio de Janeiro in 1992. Since January 1st 1994, the Swedish Forestry Act stated that the protection of environmental values is as important as the production of wood.

A further important writing is the Sector Responsibility, which implies that the forestry sector is responsible for its own forest environmental policy and for implementing this through all its activities (Törrnqvist 1995; Ingmarsson 2004; Appelstrand 2007). This implies among other things that the Forestry Act sets a minimum targets for forest owners and expects them to aim for even higher goals in terms of both environmental protection and timber production. With the government bill 'A forest policy in line with the times' to the parliament in March 2008, some changes to the current forest policy were introduced, e.g. stressing the importance of increased forest growth as well as nature protection (see Swedish Government 2008). Besides the environmental and social regulations stated in the Swedish Forestry Act, a number of other forms of regulation, prescription, goals and voluntary agreements or standards are evident, such as a set of environmental objectives concerning the forest sector titled Sustainable Forests, formally adopted by the Swedish Forest Agency in March 2005 (Swedish Forest Agency 2005). Among the more influential non-state and market-based actions are the forest certification standards Forest Stewardship Council (FSC) and the Programme for the Endorsement of Forest Certification Schemes (PEFC) introduced in the late 1990s (Gulbrandsen 2005). It seems that forest certification goes well with the 
Swedish states' ideas on how 'sector responsibility' should be implemented in order to reach policy goals (Boström 2003). Yet, it must be considered that irrespective of whether 'strict' or 'soft' policy instruments are applied by the state-i.e. governing or governance in the words of Appelstrand (2007) - the policy-makers have to understand the target groups and their goals and behaviour. This is equally true both for designing and introducing the policy instruments and for evaluating their effects.

From previous research it is known that the 'economic man' concept is not sufficient to understand and predict small-scale forest owners' behaviour because a variety of management goals and ideas exists among the owners on how to maintain and increase the benefits from their forests (Törnqvist 1995; Ingmarsson 2004; Lidestav and Nordfjell 2005). However, to most of today's forest owners, recreation, housing and the possibility to stay in contact with their place of birth are considered of higher value than forest income (Lidestav and Nordfjell 2005). Given their increasingly diverse population, a number of efforts have been made to identify and characterize sub-groups of forest owners. In most cases the focus has been on their (differing) willingness to harvest as discussed by Fischer et al. (2010), but there are also some studies on attitudes to precommercial thinning (e.g. Fällman et al. 2005) and nature conservation policies (e.g. Uliczka et al. 2004). Some studies have also investigated small-scale forest owners' attitudes to policy instruments, or attempted to identify and characterize forest owner groups that generally are difficult to reach with traditional extension methods or programs, such as women and non-resident owners (Andersson 1999; Lidestav and Staal Wästerlund 1999; Frohm et al. 2001; Lidestav and Lundell 2001; Ingmarsson 2004).

In most cases, the studies have been carried out as interview surveys or postal surveys and only occasionally have two or more data sources been combined. However, important differences have been found when comparing results from forest field studies of pre-commercial thinning estimated by the National Forest Inventory and results from the annual survey by the Swedish Forest Agency (Pettersson and Bäcke 1998). Furthermore, when Lundqvist (2003) compared the results from a field survey regarding regeneration measurements with the forest owner's opinions of the same regeneration measurement, he found that many forest owners believed that their regeneration was adequate even when it clearly failed to meet the standard set by the Swedish Forestry Act (Swedish Forestry Agency 2003). When evaluating the national forest policy, the Swedish Forest Agency also expressed concern regarding the small-scale forest owners' capacities to implement their own expressed interest in silivicultural and environmental investments (Danielsson et al. 2001). To sum up, there is a mutual interest and need from researchers, policy-makers and forest authorities to develop methods and survey designs to better and continuously validate and guarantee the quality of surveys with the intention to predict the effect of a new policy as well as to follow up how people conform to the policies.

In response to this need for more detailed, reliable and accessible data, a database for forest owner analysis has been developed. The objective of this paper is to provide a detailed description of the database, identify its strengths and weaknesses, and illustrate how it can be used. Besides featuring the database as a source for baseline survey and analysis of Swedish small-scale forestry, a secondary objective is to provide an example 
of an approach that could be useful in other countries with a high proportion of smallscale forest ownership.

\section{Description of the Data Base for Forest Owner Analysis (DBFOA)}

The database consists of data from an annually recurrent survey regarding cuttings and silviculture in small-scale forestry, gathered by the Swedish Forest Agency since 1992. An annual questionnaire is sent to a random sample of registered forest owners. With telephone guidance from a forest ranger at the Swedish Forest Agency, the owners answer the questions and provide comments on the reported activities for each of their holdings with respect to the previous year. In a few cases some questions appear only for one or 2 years. At present, data for more than 32,000 small-scale forest management units, with a size of 5 to 5,000 ha, owned by a physical or juridical person with less than 10 forestry employees, are included in the database. A management unit is made up of one or more holdings owned by the same owner or a group of owners within the same municipality. A sample stratified by county and holding size is selected from the target population of small-scale forest management units in Sweden as described by Lidestav and Lindén(1996). In 2004, the grouping of forest area classes was modified, with merging of the previous area classes 5-25 ha and 25-49 ha, and also 200-399 ha and 400-999 ha. The database also contains information about the registered owner's gender and age, whether they are resident within the same municipality as the management unit, the total number of owners, and whether any self-activity in harvesting or silviculture has occurred. In addition, area and volume of final felling, cleaning, other cuttings, thinning and scarification, planting, supplementary planting, sowing, fertilization as well as property area are recorded in the database. Information on forest certification has been included since 1999. It has not been practicable to re-establish the connection between the land registry and the specific answers given by the individual owners from 1995 to 1998 , and therefore reported activity cannot be matched to the forest owners for that period. From 1995 to 1997 data concerning population and sample size are lacking, although the sampling fraction is known for these years. A comprehensive overview of the database contents is presented in "Appendix".

Table 1 summarizes the target population, sample size, number of respondents and response rate for the period 1992-2008. The response rate averaged 85\% for 1999-2003. On January 2005 the severe storm 'Gudrun' hit the southern part of Sweden, especially the province of Småland, with many small-scale forest owners suffering major losses of forest which was ready for thinning or final felling. This catastrophe is reflected in the large drop in the number of responses for 2004 (53.2\%), the questionnaire for reported activity during 2004 being distributed to forest owners in January 2005. Most likely 'Gudrun', together with the subsequent storm called 'Per' that occurred in January 2007, substantially reduced the response rate for 2004, 2005 and 2006. 
Table 1 Total number of management units in the population and sample, number of respondents and response rate for the forest owner surveys, 1992-2008

\begin{tabular}{llllc}
\hline Year & Population size & Sample size & $\begin{array}{l}\text { Number of } \\
\text { respondents }\end{array}$ & $\begin{array}{c}\text { Response rate } \\
\text { (\%) }\end{array}$ \\
\hline 1992 & 206,803 & 2,236 & 2,061 & 92.2 \\
1993 & 203,474 & 2,232 & 2,046 & 91.7 \\
1994 & 203,520 & 2,249 & 2,080 & 92.5 \\
1995 & a & a & 2,280 & b \\
1996 & a & a & 2,322 & b \\
1997 & a & a & 2,250 & b \\
1998 & 202,191 & 2,230 & 2,025 & 90.8 \\
1999 & 202,480 & 2,235 & 1,902 & 85.1 \\
2000 & 200,379 & 2,237 & 1,864 & 83.3 \\
2001 & 199,458 & 2,239 & 1,919 & 85.7 \\
2002 & 199,194 & 2,236 & 1,911 & 85.5 \\
2003 & 199,569 & 2,247 & 1,923 & 85.6 \\
2004 & 198,056 & 2,240 & 1,192 & 53.2 \\
2005 & 197,033 & 2,229 & 1,732 & 77.7 \\
2006 & 196,169 & 2,192 & 1,680 & 76.6 \\
2007 & 194,130 & 2,181 & 1,716 & 78.7 \\
2008 & 194,432 & 2,180 & 1,789 & 82.1 \\
\hline a & & $b$ & &
\end{tabular}

a The sampling fraction is available Response rate probably similar to that for 1992-1994

\section{Use of the Database}

The database makes possible the comparison of owner categories and activities between regions. Because data can be identified at the municipality level, there is large flexibility in how regions can be arranged and defined. For example, younger owners could be compared with older owners, single owners with multiple owners, and owners of smaller units with those of larger units. Two applications of using the database are presented. One concerns assessment of forest certification and one concerns differences between male and female owners in final felling and planting.

\section{Assessment of Forest Certification Among Categories of Forest Owners}

An examination of the extent of forest certification within pairs of owner categories was performed for the years 1999-2006. Certification standards given in the DBFOA dataset are PEFC (Programme for the Endorsement of Forest Certification schemes), FSC (Forest Stewardship Council) and 'other standards'. The categories were self-active or not self-active, male or female, and resident or non-resident small-scale forest owner. Self-activity is defined as forestry work performed by owners on their own properties, or by a member of the family or someone directly employed by the forest owner. The total number of management units examined was 11,665 of which 1955 were certified. Typically, certification was found to increase with size of the management unit (Table 2). This is evident for all examined categories except for female owners, which show a 
similar relative frequency in all area classes larger than 50 ha. Whether this is a consequence of the fact that management units owned by women are in general smaller than those owned by men (as observed by Lidestav and Nordfjell 2005) has not been investigated in this study. However, further analysis of the database may provide the answer.

As indicated in Table 3, the degree of management activity for the years 1999-2006 was generally higher on certified management units than on non-certified management units. Final felling was performed on almost twice as many certified forest properties and planting occurred on almost three times as many. Also in thinning and cleaning there are substantial differences between certified and non-certified properties.

\section{Assessment of Differences Between Gender in Final Felling and Planting 1999-2006}

The development of final felling and planting activities for female and male owner categories was examined. In Fig. 1 the ratio of felled and respectively planted area in relation to total forest area of the management unit are presented for women and men owners' separately. The considerable variation in final felling reflects, to a large extent, the timber demand situation and the two to three year time lag between final felling and planting. In contrast to previous findings by Lidestav and Ekström (2000), there was more final felling on female than male forest owners' land during 2003-2006, while the planting activity, taken as a whole for the entire period, does not seem to differ.

\section{Discussion}

As pointed out by Ingmarsson (2004), continuous monitoring of small-scale forest owners is crucial, due to the continuing changes in ownership structure. By the examples chosen, the intention has been to demonstrate the potential use of the database, both in relation to some general structural trends within small-scale forest ownership, and regarding forest policy within the broad framework of Sustainable Forest Management. The certification example relates to the thematic elements of biological diversity, the productive functions, and the legal, policy and institutional framework. In contrast to decreased harvest predicted in the scenarios presented by Eriksson et al. (2006a), DBFOA-based analysis reveals higher forestry activity on certified properties. However, the reasons for the higher activity cannot be explained by further analysis of the database. Supplementary questions addressing the small-scale forest owner's incentives will be needed to address this question. A survey addressing these questions is in progress within a continuing project being conducted by the authors, where forest owners with certified forest land are involved in a follow-up survey. As a further area of research, field data are needed to decide whether the environmental outcomes really meet the policy expectations. A suitable methodological approach would then be to combine DBFOA data with data from a follow-up survey, and with National Forest Inventory data corresponding to the interim targets found in the Sustainable Forest objectives. A similar approach would also be applicable for an evaluation of whether the Green forest 
management plans (a requirement for forest certification) really work as a policy tool. Although the issue has been addressed by Ingmarsson (2004) it has not yet been resolved satisfactorily.

Table 2 Relative frequency of forest certification by area class and ownership category

\begin{tabular}{|c|c|c|c|c|c|c|c|}
\hline \multirow{2}{*}{$\begin{array}{l}\text { Area class } \\
\text { (ha) }\end{array}$} & \multicolumn{2}{|c|}{ Self-activity (\%) } & \multicolumn{2}{|c|}{ Gender (\%) } & \multicolumn{2}{|c|}{ Resident (\%) } & \multirow[t]{2}{*}{ All (\%) } \\
\hline & Yes & No & Female & Male & Yes & No & \\
\hline $5-49$ & 9 & 5 & 6 & 8 & 8 & 7 & 8 \\
\hline $50-199$ & 20 & 14 & 16 & 19 & 18 & 17 & 18 \\
\hline 200-999 & 24 & 19 & 19 & 24 & 23 & 21 & 22 \\
\hline$\geq 1000$ & 34 & 31 & 18 & 39 & 38 & 33 & 32 \\
\hline
\end{tabular}

Table 3 Relative frequency of management activities on certified and non-certified forest management units

\begin{tabular}{lcc}
\hline Forest activity & Certified forest (\%) & Non-certified forest (\%) \\
\hline Final felling & 32 & 17 \\
Thinning & 50 & 29 \\
Cleaning & 51 & 32 \\
Scarification & 18 & 7 \\
Planting & 31 & 12 \\
Other cuttings & 52 & 44 \\
\hline
\end{tabular}




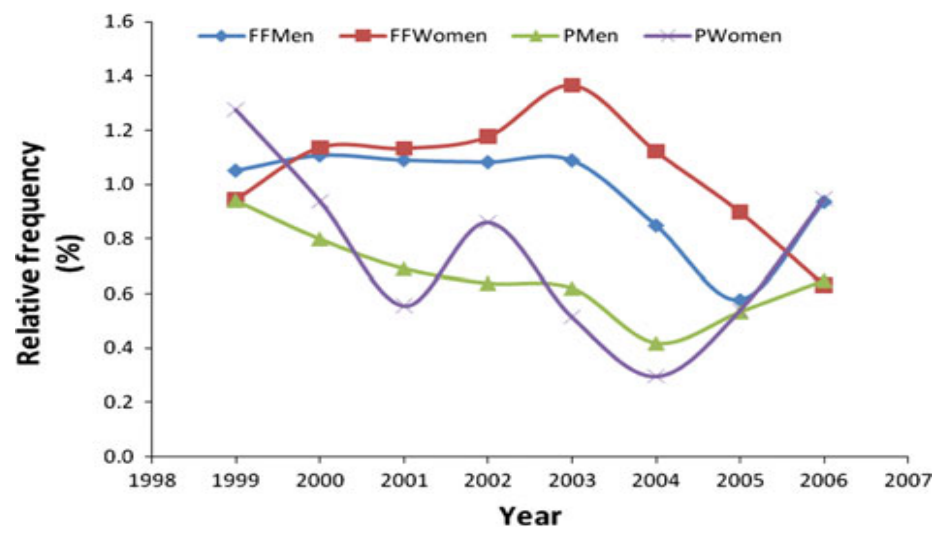

Fig. 1 Activity ratio of final felling area $(\mathrm{FF})$ and planting area $(\mathrm{P})$ in relation to total area of management units owned by men and women

The second example primary relates to the thematic elements of 'productive functions of forest resources', and 'legal, policy and institutional framework'. As recognized by two of the major small-scale forestry 'service providers', the Swedish Forest Agency and the Federation of the Forest Owners Associations, new and previously over-looked categories of forest owners (e.g. women) require special attention in terms of extension services and educational programs (Frohm et al. 2001; Lidestav and Lundell 2001). Whether the increased awareness and extension services directed towards female forest owners may explain the higher final felling activity among female owners presented in Fig. 1 or not, a more thorough statistical analysis is needed. Such an analysis is also underway in a continuing study by the authors, with the purpose of examining the possible impact of an increased awareness and extension services directed towards female forest owners. In this forthcoming study, the same methodology as Lidestav and Ekström (2000) applied on data from 1992-1994 (now included in the DBFOA) will be used. That is, differences in frequency of harvesting and silvicultural operations will be examined by binary logistic regression and differences in harvesting volume tested by ztest.

As indicated by the examples above, a number of comparative studies of ownership and activity trends over time can be examined, separately or in combination with other data sources. DBFOA provides data detailed enough to examine how different smallscale forest owner segments act in response to general structural changes such as urbanization and mechanization of harvesting operations and forest policy changes. For example, the general observation of a substantial reduction in pre-commercial thinning (PCT) after the introduction of a the Swedish Forestry Act from 1994 (which abolished the previous obligation of PTC) can be analyzed by region, size of the forest holding, age and gender of the owner, ownership type (sole owner or in conjunction with others), residential or nonresidential ownership, and degree of self-activity. Further, when evaluating the impact of awareness campaigns, such as the 'The Greener Forest' campaign by the Swedish Forest Agency or 'Kraftsamling skog' run by the Federation of the Forest Owners Association LRF Skogsägarna (2010) the DBFOA can be used for 
providing baseline activity information.

It should be recognized that the activity data in the DBFOA are self-reported, giving the respondents view of the activities undertaken. The fact that the data are collected with telephone guidance from a forest ranger with local knowledge may on one hand reduce misunderstandings and deliberate false reports, but on the other hand there is a risk of 'over-reporting', i.e. a well-known tendency for respondents to want to please the interviewer (Frey and Mertens Oishi 1995). In order to determine any such bias, validation studies will be a continuing research activity.

Apart from the general tendency of overestimation, the DBFOA is considered to be of high quality. The design and data collection procedure have been tested, found to be efficient, and performed in the same way since 1992. However, the lack of data regarding individual owners for the period 1995-1998 is a drawback. A response rate of $75 \%$ or more is very high, both in national and international contexts, and leads to a high probability of producing a reliable dataset. One reason for the high response rate is the limited numbers of questions which focus only on work performed. Another is that there are no questions on people's opinions or reasons for actions or lack of actions. The database can therefore preferably be used to establish a baseline, serving as a point of departure for developing more in-depth research surveys. 


\section{References}

Andersson R (1999) Analysis of target groups as a way to develop forestry training for groups that are hard to reach. In: Proceedings from the Joint FAO/ECE/ILO Committee on Forest Technology, Management and Training Seminar on Forestry Training for Target Groups that are Hard to Reach, held at Provence-Alpes-Cote d'Azur Regional Forestry Centre, La Bastide des Jourdans, France, 20-24 April 1998 Centre forestier de la Re'gion Provence Alpes Co`te d'Azur, France

Appelstrand M (2007) Miljömål i skogsbruket—styrning och frivillighet, Lund studies in sociology of law, 26. Lund University. Doctoral thesis. (In Swedish with English summary)

Boström M (2003) How state-dependent is a non-state-driven rule-making project? The case of forest certification in Sweden. J Environ Policy Plan 5(2):165-180

Danielsson B, Andersson R, Gottne G, Holmgren L, Karlsson S, Lönnstedt L, Törre M (2001) De skogliga aktörerna och skogspolitiken. Rapport 8H. Skogsstyrelsen förlag, Jönköping

Eriksson LO, Ola Sallnäs O, Sta ${ }^{\circ}$ l G (2006a) Forest certification and Swedish wood supply. For Policy Econ 9(5):452-463

Eriksson O, Sallnäs O, Ståhl Göran (2006b) Forest certification and Swedish wood supply. For Policy Econ 9(5):452-463

Fällman K, Albrektson A, Karlsson A (2005) Private forest owners in Sweden and their attitude towards precommercial thinning. In: Fa"llman K (ed) Aspects of precommersial thinning - private forest owners attitudes and alternative practices. Swedish University of Agricultural Sciences, Dissertation. Acta Universitatis Agriculturae Sueciae Silvestria, Umeå

FAO (2010) Sustainable forest management http://www.fao.org/forestry/sfm/24447/en/. (Accessed 6 April 2010)

Fischer P, Bliss J, Ingemarson F, Lidestav G, Lönnstedt L (2010) From the small woodland problem to ecosocial systems: The evolution of social research on smallscale forestry in Sweden and the USA. Scan J For Res 25:390-398

Frey JH, Mertens Oishi S (1995) How to conduct interviews by telephone and in person. Sage Publications, California

Frohm S, Holmgren L, Andersson R (2001) How to meet women in forestry? Experiences of the Swedish forest administration on extension service to female forest owners. In: Seminar Proceedings. Women in forestry: strategies to increase women's participation in the forestry sector in Europe and North America, Viseu, Portugal 2-6 April 2001. Joint FAO/ECE/ILO Committee on forest technology, management and training. Direccao-Geral das Florestas, Lisbon

Gulbrandsen LH (2005) The effectiveness of non-state governance schemes: a comparative study of forest certification in Norway and Sweden. Int Environ Agreem 2005(5):125-149, Springer

Hirshleifer J (1985) The expanding domain of economics. Am Econ Rev 75(6):53-68

Hyttinen P, Kallio T (2001) Farmforestry as socio-economic and ploitical Issue. In: Niskanen A, Sekot W (eds) Guidelines for establishing farm forestry accountancy networks. European Forest Institute Research Report 123

Ingmarsson F (2004) Small-scale forestry in Sweden: owners' objectives, silvicultural practices and management plans. Department of Forest Products and Markets, 
Swedish University of Agricultural Sciences, Dissertation. Acta Universitatis Agriculturae Sueciae Silvestria, Uppsala

Lidestav G, Ekström M (2000) Introducing gender in studies on management behaviour among nonindustrial private forest owners. Scand J For Res 15(3):378-386

Lidestav G, Berg Lejon S. Forest certification as an instrument for improved management within small-scale forestry (forthcoming in small-scale forestry)

Lidestav G, Lindén H (1996) Förslag till metod för bestämning av prestationstal m.m. vid självverksamhet i småskaligt skogsbruk. Rapport 4-1996. Skogsstyrelsen förlag, Jönköping

Lidestav G, Lundell S (2001) Developing a female forest owner tradition with a 'Dutch party approach'. In: Seminar Proceedings. Women in forestry: strategies to increase women's participation in the forestry sector in Europe and North America, Viseu, Portugal 2-6 April 2001. Joint FAO/ECE/ILO Comittee on forest technology, management and training. Direccao-Geral das Florestas, Lisbon, pp 249-258

Lidestav G, Nordfjell T (2005) A conceptual model for understanding social practices in family forestry. Small-scale For Econ Manag Policy 4(4):391-408

Lidestav G, Staal Wästerlund D (1999) Training of female forest owners in Sweden. In: Proceedings from the Joint FAO/ECE/ILO Committee on Forest Technology, Management and Training Seminar on Forestry Training for Target Groups that are Hard to Reach, held at Provence-Alpes-Cote d'Azur Regional Forestry Centre, La Bastide des Jourdans, France, 20-24 April 1998. Centre forestier de la Re'gion Provence Alpes Co^te d'Azur, France

LRF Skogsägarna (2010) http://www.lrf.se/Medlem/Foretagande/Skogsbruk/Kraftsamling-Skog/OmKraftsamling-Skog/. (Accessed 12 May 2010)

Lundqvist F (2003) Skogsföryngring - åtgärder och synsätt bland privata skogsägare i Mellannorrland. Master thesis, Inst f skogsskötsel, SLU. Examensarbeten 20042006, Umeå

Pettersson B, Bäcke J (1998) Röjningsundersökningen 1997. Meddelanden 7-1998. Skogsstyrelsens förlag, Jönköping

Swedish Forest Agency (2005) Quantitative targets of Swedish forest policy. Swedish Forest Agency, Jönköping

Swedish Forestry Agency (2003) Handbok till skogsvårdslagen. Swedish Forestry Agency, Jönköping

Swedish Government (2008) En skogspolitik i takt med tiden. Regeringens proposition 2007/08:108. (A forest policy in line with the times, Government bill 2007/2008:108). http://www.regeringen.se/sb/ d/9700/a/101011 (Accessed April 2010)

Törnqvist T (1995) Skogsrikets arvingar. En sociologisk studie av skogsägarskapet inom privat, enskilt skogsbruk [Inheritors of the woodlands: a sociological study of private, non-industrial forest ownership - a sociological study of the ownership in private forestry]. Doctoral thesis, Report no 41, Swedish University of Agriculture Sciences, Uppsala. (In Swedish with English Summary)

Uliczka H, Angelstam P, Jansson G, Bro A (2004) Non-industrial private forest owners' knowledge of and attitudes towards nature conservation. Scand J For Res 19(3):274288 
Appendix A. Data contained in the Data Base for Forest Owner Analysis for the years of 1992-2008

Year of the annual survey

Ash recycling: area in ha, occurrence, self-activity

Cleaning: area in ha, occurrence, self-activity, volume in $\mathrm{m}^{3}$

County, forest owner (land registry)

County, forest management unit (land registry)

Final felling: area in ha, occurrence, self-activity in cutting and hauling, volume in $\mathrm{m}^{3}$

Forest certification: $<5$ yrs, $\geq 5$ yrs, FSC-standard, PEFC-standard, other standard

Forest fertilization: area in ha, occurrence, self-activity

Property area in ha

Property area, ha (land registry)

Sex (land registry)

Missing data

Municipality, forest owner (land registry)

Municipality, management unit (land registry)

Number of forest owner (land registry)

Other cuttings: occurrence, self-activity in cutting and off road transportation, volume in $\mathrm{m}^{3}$

Owner age (land registry)

Forest owner share of property

Planting of contorta: area in ha

Planting of contorta: self-activity \%

Planting: area in ha, occurrence, self-activity

Processing windthrow trees: occurrence, self-activity in cutting and hauling, volume $\mathrm{m}^{3}$

Procurement of logging residue in final felling, volume in $\mathrm{m}^{3}$

Procurement of logging residue in final felling: area in ha, occurrence

Procurement of logging residue in thinning, volume in $\mathrm{m}^{3}$

Procurement of logging residues in thinning: area in ha, occurrence

Pruning: area in ha, occurrence, self-activity

Self-activity, all activities

Soil scarification: area in ha, occurrence, self-activity

Sowing: area in ha, occurrence, self-activities

Supplementary planting: number of plants, occurrence, self-activity

Thinning: area in ha, occurrence, self-activity for cutting and hauling, volume $\mathrm{m}^{3}$

Type of owner (land registry)

\begin{tabular}{lllllllllllllllll}
1992 & 1993 & 1994 & 1995 & 1996 & 1997 & 1998 & 1999 & 2000 & 2001 & 2002 & 2003 & 2004 & 2005 & 2007 & 2006 & 2008 \\
\hline
\end{tabular}

Working hours

\begin{tabular}{|c|c|c|c|c|c|c|c|c|c|c|c|c|c|c|c|c|}
\hline & & $x$ & $x$ & $x$ & $x$ & $x$ & $x$ & $x$ & $x$ & $x$ & $x$ & $x$ & $x$ & $x$ & $x$ & $x$ \\
\hline \multirow[t]{2}{*}{$x$} & $x$ & $x$ & $x$ & $x$ & $x$ & $x$ & $x$ & $x$ & $x$ & $x$ & $x$ & $x$ & $x$ & $x$ & $x$ & $x$ \\
\hline & & & & & & & $x$ & $x$ & $x$ & $x$ & $x$ & $x$ & $x$ & $x$ & $x$ & $x$ \\
\hline$x$ & $x$ & $x$ & $x$ & $x$ & $x$ & $x$ & $x$ & $x$ & $x$ & $x$ & $x$ & $x$ & $x$ & $x$ & $x$ & $x$ \\
\hline \multirow[t]{2}{*}{$x$} & $x$ & $x$ & $x$ & $x$ & $x$ & $x$ & $x$ & $x$ & $x$ & $x$ & $x$ & $x$ & $x$ & $x$ & $x$ & $x$ \\
\hline & & & & & & & $x$ & $x$ & $x$ & $x$ & $x$ & $x$ & $x$ & $x$ & $x$ & $x$ \\
\hline$x$ & $x$ & $x$ & $x$ & $x$ & $x$ & $x$ & $x$ & $x$ & $x$ & $x$ & $x$ & $x$ & $x$ & $x$ & $x$ & $x$ \\
\hline$x$ & & $x$ & $x$ & $x$ & $x$ & $x$ & $x$ & $x$ & $x$ & $x$ & $x$ & $x$ & $x$ & $x$ & $x$ & $x$ \\
\hline$x$ & $x$ & $x$ & $x$ & $x$ & $x$ & $x$ & $x$ & $x$ & $x$ & $x$ & $x$ & $x$ & $x$ & $x$ & $x$ & $x$ \\
\hline \multirow[t]{3}{*}{$x$} & $x$ & $x$ & & & & & $x$ & $x$ & $x$ & $x$ & $x$ & $x$ & $x$ & $x$ & $x$ & $x$ \\
\hline & & & & & & & & & & & $x$ & $x$ & $x$ & $x$ & $x$ & $x$ \\
\hline & & & & & & & $x$ & $x$ & $x$ & $x$ & $x$ & $x$ & $x$ & $x$ & $x$ & $x$ \\
\hline$x$ & $x$ & & & & & & $x$ & $x$ & $x$ & $x$ & $x$ & $x$ & $x$ & $x$ & $x$ & $x$ \\
\hline$x$ & $x$ & $x$ & & & & & & & & & $x$ & $x$ & $x$ & $x$ & & $x$ \\
\hline$x$ & $x$ & $x$ & $x$ & $x$ & $x$ & $x$ & $x$ & $x$ & $x$ & $x$ & $x$ & $x$ & $x$ & $x$ & $x$ & $x$ \\
\hline \multirow[t]{2}{*}{$x$} & $x$ & $x$ & & & & & $x$ & $x$ & $x$ & $x$ & $x$ & $x$ & $x$ & $x$ & $x$ & $x$ \\
\hline & & & & & & & $x$ & $x$ & $x$ & $x$ & $x$ & $x$ & $x$ & $x$ & $x$ & $x$ \\
\hline \multirow[t]{2}{*}{$x$} & $x$ & $x$ & & & & & & & & & $x$ & $x$ & $x$ & & & \\
\hline & & $x$ & & & & & & & & & $x$ & $x$ & $x$ & & & \\
\hline \multirow[t]{6}{*}{$x$} & $x$ & $x$ & $x$ & $x$ & $x$ & $x$ & $x$ & $x$ & $x$ & $x$ & $x$ & $x$ & $x$ & $x$ & $x$ & $x$ \\
\hline & & & & & & & & & & & $x$ & $x$ & $x$ & & & \\
\hline & & & & & & & & & & & & & & $x$ & & $x$ \\
\hline & & $x$ & $x$ & $x$ & $x$ & $x$ & $x$ & $x$ & $x$ & $x$ & $x$ & $x$ & $x$ & $x$ & $x$ & $x$ \\
\hline & & & & & & & & & & & & & & $x$ & & $x$ \\
\hline & & $x$ & $x$ & $x$ & $x$ & $x$ & $x$ & $x$ & $x$ & $x$ & $x$ & $x$ & $x$ & $x$ & $x$ & $x$ \\
\hline$x$ & $x$ & & & & & & & & & & $x$ & $x$ & $x$ & & & \\
\hline$x$ & $x$ & $x$ & $x$ & $x$ & $x$ & $x$ & $x$ & $x$ & $x$ & $x$ & $x$ & $x$ & $x$ & $x$ & $x$ & $x$ \\
\hline \multirow[t]{2}{*}{$x$} & $x$ & $x$ & $x$ & $x$ & $x$ & $x$ & $x$ & $x$ & $x$ & $x$ & $x$ & $x$ & $x$ & $x$ & $x$ & $x$ \\
\hline & & $x$ & $x$ & $x$ & $x$ & $x$ & $x$ & $x$ & $x$ & $x$ & $x$ & $x$ & $x$ & $x$ & $x$ & $x$ \\
\hline$x$ & $x$ & $x$ & $x$ & $x$ & $x$ & $x$ & $x$ & $x$ & $x$ & $x$ & $x$ & $x$ & $x$ & $x$ & $x$ & $x$ \\
\hline$x$ & $x$ & $x$ & $x$ & $x$ & $x$ & $x$ & $x$ & $x$ & $x$ & $x$ & $x$ & $x$ & $x$ & $x$ & $x$ & $x$ \\
\hline$x$ & $x$ & $x$ & $x$ & $x$ & $x$ & $x$ & $x$ & $x$ & $x$ & $x$ & $x$ & $x$ & $x$ & $x$ & $x$ & $x$ \\
\hline$x$ & $x$ & $x$ & $x$ & $x$ & $x$ & $x$ & $x$ & $x$ & $x$ & $x$ & $x$ & $x$ & $x$ & & & \\
\hline
\end{tabular}

